element of discussion or personal assessment." It was not, of course, the purpose of the interview to carry out a personal assessment. Applicants are very rarely given interviews and the main reason for this interview was to discuss the problems created by her state of health and her family commitments, which, she pointed out, made it essential for a training practice to be found near her home. The interview, at which the regional adviser in general practice was also present, lasted more than 45 minutes. The same day we sent a letter to Dr Bankole reminding her that she had agreed to take up the regional adviser's offer of a further meeting as soon as possible to assist her in finding a suitable training practice in which she could complete the recommended four months' training on a part-time basis. Although that offer was never taken up by Dr Bankole, it remains open.

J D J Havard

D H IRvine

Joint Committee on Postgraduate

Training for General Practice,
London SW 7 1PU

SIR,-I sympathise with Dr Naomi Bankole, (21 August, p 566) and her attempts at fulfilling the requirements set for her by the Joint Committee on Postgraduate Training for General Practice (JCPTGP). I had similar difficulties but managed to overcome them.

In October 1980 I decided to apply for the certificate of equivalent training for general practice after two years in general practice in rural Canada and three years in SHO posts in the UK. I decided that this was necessary as I had applied for partnerships in England for several months without success, and I thought that being eligible for the vocational training allowance would be an additional qualification, even though the trainee year in general practice was not mandatory until February 1981.

In February 1981 I received the JCPTGP's decision that I would have to complete only three months as a trainee. This at first seemed very generous, but it became apparent after months of applying to advertisements for trainee vacancies that practices were very reluctant to take a trainee for only three months. I wrote to several regional advisers in general practice asking them about possible three-month traineeships without success.

In October 1981 time was running out as my hospital experience would fail to count after August 1982 under the seven-year rule. I decided to drive the 3000 -mile round trip to the BMA congress in San Diego from Alberta. There I placed a notice on the board and managed to receive five replies, but three of them were to tell me that I had wrongly interpreted the vocational training regulations and that the trainee period was one year. There was, in fact, only one definite offer and that was for a period commencing only five weeks later. Fortunately I was able to arrange a locum for my practice in Southern Alberta, although I had to fly back for the Christmas period to cover my own practice.

In retrospect it would have been easier and much less of a financial burden to not have applied for any exemption from the requirements and to have completed the full 12 months as a trainee in general practice from October 1981. This would have been advisable in Dr Bankole's case too. If she had applied and been accepted for a traineeship for 12 months from May 1981 she would have managed to have beaten the deadline of August 1982 and not have been excluded from general practice as a principal for the rest of her life, providing she could have worked full time.

I am unsure of Dr Bankole's comments on the letter to her prospective trainer from the Department of Health regarding payment to the trainer. I feel there must have been some misinterpretation either by the Department of Health or the trainer as there was no difficulty in my case or that of other trainees that I have met who have had shortened traineeships.

The requirements of the Vocational Training Act have made it very difficult for doctors to enter general practice on their return from abroad, even though they may have been practising primary care in a very broad sense. I would recommend that anyone contemplating a period overseas should complete the full requirement prior to their departure, and I suggest that doctors returning to the UK do not apply to the JCPTGP for exemption as shortened traineeships in general practice appear hard to find, partly because trainers do not seem to appreciate that partial exemption is sometimes granted by the JCPTGP.

Even after receiving the certificate some practices do not think the holder is eligible to become a principal if his experience has departed from the precise requirements of the Vocational Training Act.

D BRACHER

Plymouth PL2 3LG

\section{Water intoxication and oxytocin}

SIR,-Further to Dr Naomi Bankole's "Personal View" (21 August, p 566) I think that the ultimate irony is that someone with eight months' general practice experience in 1968 followed by many years in Nigeria should now hold a post as senior registrar in community medicine "helping to assess and integrate general practitioner services within the primary care structure.",

It seems clear that in her view Dr Bankole's experience of general practice, almost wholly in Nigeria, makes her quite suited to be a principal in British general practice. Not surprisingly the Joint Committee on Postgraduate Training for General Practice disagrees-it has to abide by the Vocational Training Act. Is it also her view that she has the experience and knowledge of British general practice "to assess and integrate it into the primary care structure"-whatever that may mean?

\section{B A Crompton}

Skegness, Lincs

SIR,-It is surely essential for doctors in any specialty to have had adequate training and experience, but the medical profession is tending to make an ass of itself in relation to certain aspects of specialist training and accreditation. That is well shown by Dr Naomi Bankole's sad story (21 August, p 566) about her recent efforts to enter general practice.

When the idea of compulsory post-registration training for general practice first became known to the Joint Consultants Committee several years ago, Sir Desmond Pond and I expressed grave concern about the rigidity of the proposals and even graver concern that the training programme for prospective general practitioners would be uniquely, and highly undesirably, enshrined in Act of Parliament.

Whatever faults there may be in some of the existing specialist training programmes at least
SIR,-Your recent leading article by $\mathrm{Mr} \mathrm{J}$ G Feeney (24 July, p 243) on water intoxication is a potent reminder that convulsions may be

it is possible for the royal colleges and their faculties, together with the various committees on higher training, to effect reforms, to ensure flexibility, and to put their own houses in order. Not so with our general practitioner colleagues ("independent contractors" in a near State monopoly), who now find themselves beholden to secretaries of state and bureaucrats in the management of their training programme.

It is essential for all of us to ensure that both undergraduate and postgraduate training, so highest standards of service to the public, but it is foolish to presume that such standards are achieved only by meticulous supervision and regulation of the young. Many of the best specialists and general practitioners I know were notably eclectic in planning their own training. An old adage opines that: "There is no system of education yet devised that can keep a really good man down," but let us needlessly delay and frustrate the progress of our younger colleagues. Regrettably that is precisely what some of us are doing.

London W1N 1DF

REginald MURLEY iatrogenic. Perhaps these may become more frequent as powerful cytotoxic drugs are used in high doses to obtain cure in women with gynaecological cancer. This is illustrated by a recent tragic case.

A spry, caucasian woman, 55 years old, was referred in February 1982 with an ovarian cyst the size of a 26-week gestation. Her blood pressure was $110 / 70 \mathrm{~mm} \mathrm{Hg}$. Laparotomy showed a multiloculated ovarian tumour to which loops of small intestine and the mesentery of the sigmoid colon were adherent. The tumour was friable and during removal it ruptured and was removed piecemeal. There was no other evidence of tumour spread above the pelvic brim. The pathologist reported a papillary serous cystadenocarcinoma but found no tumour in the other ovary or the omentum. There was, however, a deposit of tumour on the ectocervix. Because the growth was considered a stage III tumour (but without histological proof) cisplatin was started on the 14th day after operation. The dose used was $100 \mathrm{mg} / \mathrm{m}^{2}$. The creatinine clearance was a little reduced at $91 \mathrm{ml} / \mathrm{minute}$. Diuresis was provided by four litres of intravenous fluid followed by $400 \mathrm{ml}$ of $10 \%$ mannitol, followed in turn by a further three litres of intravenous fluid. These fluids were given over 48 hours. The cisplatin was well tolerated although the second and third courses (given at four weekly intervals) were associated with increasing gastrointestinal upset. By the fourth treatment the blood pressure was 140/ $80 \mathrm{~mm} \mathrm{Hg}$, the creatinine $142 \mu \mathrm{mol} / \mathrm{l}(1.6 \mathrm{mg} /$ $100 \mathrm{ml}$ ), and the haemoglobin $8.4 \mathrm{~g} / \mathrm{dl}$ with a moderate neutropenia. A similar dose of cisplatin was given as on the previous occasions. The following day three units of packed red cells were transfused, and the patient was discharged 24 hours later. She was readmitted just one day later because of repeated convulsions, which were eventually controlled with diazepam $(25 \mathrm{mg})$ and intravenous $0 \cdot 8 \%$ chlormethiazole (at 40 drops $/ \mathrm{min}$ ). The blood pressure was $210 / 120 \mathrm{~mm} \mathrm{Hg}$, the plasma urea $19.6 \mathrm{mmol} / 1(118 \mathrm{mg} / 100 \mathrm{ml})$, and the haemoglobin $17 \cdot 7 \mathrm{~g} / \mathrm{dl}$. Although the convulsions were eventually controlled the patient did not regain consciousness and died 10 hours later. Necropsy revealed no evidence of tumour in the peritoneal 
cavity, no cerebral haemorrhage, and no metastases. The kidneys were unremarkable apart from microscopic changes typical of acute tubular necrosis.

This patient died from convulsions due to cisplatin being continued when the plasma creatinine, which had been rising monthly, was above $130 \mu \mathrm{mol} / 1(1.5 \mathrm{mg} / 100 \mathrm{ml})$. Undoubtedly blood was transfused at a time of electrolyte flux and may well have been a contributory factor. It is unfortunate that in the final illness neither the plasma calcium nor magnesium nor other electrolytes were estimated. ${ }^{1}$ The convulsions were probably due to a direct action of cisplatin on the central nervous system rather than hypertensive encephalopathy or electrolyte disturbance. Cisplatin is known to affect the central nervous system and cause fits as well as reversible changes in the peripheral nerves. Possibly this central effect is commoner with high doses. ${ }^{2} 3$ Strict adherence to the maker's (Bristol-Meyers Company Limited) recommendations should limit deaths from this most potent, valuable, and toxic drug.

Alan M Smith

New Cross Hospital

Wolverhampton 1 Barker GH, Wiltshaw E. Br f Obstet Gynaecol 1981;
88:1192-9.

' Barker GH, Wiltshaw E. Lancet 1981 ;i:747-50.

- Wiltshaw E. Biochemie 1978;60:925-9.

\section{Wheezing, asthma, and pulmonary dysfunction 10 years after infection with} respiratory syncytial virus in infancy

SIR,-Drs C R Pullan and E N Hey's study, "Wheezing, asthma and pulmonary dysfunction 10 years after infection with respiratory syncytial virus in infancy" (5 June, p 1665), is of interest in view of the fact that data are available on parental smoking. The authors claim that lung-flow volume measurements were reduced in the index children even when the history of parental smoking was excluded from consideration. We are not, however, told whether or not the latter children in the study and control groups were ever exposed to cigarette smoke from casual smoking of other members of the family or by exposure to smoke during their daily activities. In addition it is stated that each child had a diagnosis of respiratory syncytial virus infection, but it is not stated clearly whether or not viral or serological methods were used to determine the diagnosis.

It is important to note that at the time of the original study significantly more children with bronchiolitis were exposed to parental smoking than control children. The exposure to cigarette smoke continued throughout childhoodthat is, two-thirds of the study group versus less than half of the control group continued to be exposed to cigarette smoke between the time of the episode of bronchiolitis and the study reported 10 years after infection. The fact that the study group was $1 \mathrm{~cm}$ shorter and $1 \mathrm{~kg}$ lighter than the control group confirms the results of a previous study ${ }^{1}$ and suggests continued adverse exposure to cigarette smoke.

Studies have indicated that children exposed to cigarette smoke have a higher rate of hospitalisation ${ }^{23}$ more respiratory symptoms, ${ }^{4}$ more bed disability days, ${ }^{5}$ more respiratory symptoms during latency ${ }^{6}$ and adolescence, ${ }^{7}$ a higher risk of wheezing in atopic children, 9 and a higher incidence of abnormal pulmonary function tests. ${ }^{9}$ Additionally, Dr Pullan and Dr Hey's study suggests greater adverse effects of cigarette smoke on atopic children. Perhaps a synergism exists between atopy, exposure to cigarette smoke, and respiratory syncytial virus infection. Higher IgE concentrations have been reported ${ }^{10}$ in smokers than in non-smokers, and atopic individuals have more symptoms when exposed to cigarette smoke. ${ }^{9}$ Children passively exposed to parental smoking automatically become equivalent to light smokers based on a study of urine and salivary nicotine concentrations in passive smokers. ${ }^{11} \mathrm{~A}$ reasonable hypothesis could be stated as follows: an atopic infant exposed to cigarette smoke becomes infected with respiratory syncytia virus, which sets the stage for continued respiratory symptoms once the infection is concluded through an immunological mechanism involving constant exposure to parental cigarette smoke.

Our understanding of the impact of parenta smoking on children's respiratory disease is in the earliest stages. The study of Drs Pullan and Hey is a major contribution to the published reports.

ROBERT P YOUNES

Carney Hospital,

02124

USA

Rona RJ, Florey CdeV, Clarke GC, Chinn S. B Med F 1981;283:1363.

' Harlpa S, Davies AM. Lancet 1974;i:529-32. Lancet $1974 ;$ ii:1031-4.

Ferguson DM, Horwood
Dis Child 1980;55:358-61. Bonham GS,

- Cameron P, Kostin J, Zaks JM, et al. $f$ Allergy 1969;43:336-41.

Tager IB, Weiss ST, Rosner B, Speizer FE. Am Epidemiol 1979;110:15-26.

Bland M, Bewley B, Pollard V, Banks M. Arch Dis Child 1978;53:100-5. 530-4.

${ }^{\circ}$ Gerrard JW, et al. Ann Allergy 1980;44:261-2.

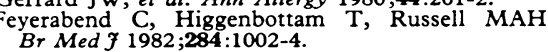

\section{St George's University School of} Medicine, Grenada: benefit or liability?

SIR,-I have to congratulate Dr Richard Smith (24 July, p 276) on a very good and very fair analysis of St George's University. I would like, however, to take this opportunity to comment on one or two points in his article. Professor Rhodes is quoted as saying there is no practical work in the basic medical sciences except anatomy. At St George's University we teach gross anatomy, histology, and neuroanatomy as independent subjects. We have a first-class gross anatomy laboratory with generous supply of bodies. We have a histology laboratory, with a modern binocular micro scope for each student and bench projectors for every two students, which is as good as any histology laboratory in any medical school anywhere and better than most. We have a fine neuroanatomy laboratory, which doubles as a laboratory for teaching pathology. In addition, there is an excellent laboratory where pathology II and microbiology are taught. We also have an excellent medical library with 350 curren journals. We do not have a physiology teaching laboratory or a biochemistry teaching laboratory, but neither has the University of Oklahoma and many other US schools. On the other hand, there is much excellent audiovisual material available in physiology to which the students are exposed. There also are pathology and clinical biochemistry laboratories in the general hospital on the islands of both Grenada and $\mathrm{St}$ Vincent to which we have access although they are not very well equipped as yet. I believe Dr Rhodes' comment about laboratories does not do us justice.

Dr Smith mentions a photograph in one of our newsletters showing the chancellor climbing into the school's plane and implies that this does not indicate that the school is pressed for funds. It is true that when the chancellor is in Grenada, he uses the plane for transportation from campus to campus. The plane is not, however, a luxury for the chancellor; it is a real workhorse. It serves the vice-chancellor, visitng professors, and faculty; transports equipment and supplies from Barbados, which would otherwise remain there for weeks or months waiting for the limited commercial airfreight service to Grenada ; and it is also available for medical emergencies when medical facilities not in Grenada are urgently required.

Dr Smith mentions the question of whether the school has brought any advantages to Grenada or whether it is there in a parasite capacity. I do not think anyone in Grenada, from the Prime Minister down, would agree that we are parasites. Firstly, we are a Grenadian School, established by act of the Grenadian Government in 1975. We provide 100000 US dollars a year to the hospital; we give the Government a cheque for 75000 US dollars a year in addition; and the school's activities put more than five million US dollars a year into the Grenadian economy, represenitng nearly one-fifth of its annual operating budget. The school is the largest single employer of labour on the island; the school pays the entire salaries of four registrars and one consultant at the hospital and supplements the salaries of at least six other consultants. The school's professor of pathology oversees pathology for the Government in all its medical facilities and is upgrading the pathology laboratory; he is also organising a blood bank (which has been nonexistent to date), and he is instituting a survey of children entering the hospital and clinics for genetic metabolic defects. The school provides five scholarships a year for Grenadian students-this represents more places than there are applicants to fill. The students have established a benevolent fund and contribute to it by giving concerts and by other means; this fund is used exclusively to support needy Grenadians or Grenadian institutions. Students, faculty, and visiting professors help in the music society, sports training, training technicians, nutrition, and in many other areas. The school has also been responsible for sending Grenadians to New York. for open-heart surgery and, in one case, to receive an artificial leg paid for by the school. The Prime Minister left no doubt that the school was of great benefit to Grenada and that his Government appreciated it during his speech at the latest graduation ceremony in Grenada. Members of the private commercial sector have advised me personally that it would be a disaster for Grenada if the school left the island. I should also like to mention that the school also fulfils most of these functions for the neighbouring island of St Vincent.

I would like to make one final point. In his conclusion, Dr Smith says, "Many people find the idea of a remote and less than adequately equipped medical school cashing in on the urgent need for some rich youngsters to become doctors rather distasteful." The idea that our students are "rich youngsters" is widespread and is incorrect. While we do have a number of rich students (many are the offspring of American doctors), most are students who are financially squeezed. For one thing, onequarter of our students are on school loans. We have students whose expenses are met by a group of doctors in the US, a group of dentists, a religious group, a group of citizens from their home town, by scholarships from foundations, by individuals, and by wives who stay in well paid jobs in the US to support the student while he qualifies. In the case of African students, there are a few who are rich, but most are on government or United 